\title{
Bacterial-based additives for the production of artificial snow: What are the risks to human health?
}

\section{Arnaud LAGRIFFOUL ${ }^{\text {a }}$, Jean-Luc BOUDENNE ${ }^{b}$, Rafik ABSI ${ }^{c}$, Jean-Jacques BALLET $^{\mathrm{d}}$, Jean-Marc BERJEAUD ${ }^{\mathrm{e}}$, Sylvie CHEVALIER ${ }^{\mathrm{f}}$, Edmond E. CREPPY ${ }^{\mathrm{g}}$, Eric GILLI ${ }^{\mathrm{h}}$, Jean-Pierre GADONNA $^{\mathrm{c}}$, Pascale GADONNA-WIDEHEM ${ }^{\mathrm{i}}$, Cindy E. MORRIS ${ }^{\mathrm{j}}$, and Sylvie ZINI ${ }^{\mathrm{a}^{*}}$}

${ }^{a}$ Agence Française de Sécurité Sanitaire de l'Environnement et du Travail, 253, avenue du Général Leclerc, 94701 Maisons-Alfort, France

${ }^{\mathrm{b}}$ Université de Provence, Laboratoire Chimie Provence, UMR6264, 3 place Victor Hugo case 2913331 Marseille cedex 3, France

${ }^{\mathrm{c}}$ Institut Polytechnique Saint-Louis, Ecole de Biologie Industrielle, 32 boulevard du Port, 95094 Cergy-Pontoise, France

${ }^{\mathrm{d}}$ Laboratoire d'immunologie et immunopathologie, Centre hospitalo-universitaire de Caen, avenue de la côte de nacre 14000 Caen, France

${ }^{\mathrm{e}}$ Université de Poitiers, Laboratoire de Chimie et Microbiologie de 1'Eau, UMR6008, 40 avenue du recteur Pineau, 86022 Poitiers cedex

${ }^{\mathrm{f}}$ Université de Rouen, Laboratoire de Microbiologie du Froid, Signaux et MicroEnvironnement, EA 4312, Normandie Sécurité Sanitaire, 55 rue St Germain, 27000 Evreux, France

g Université Bordeaux 2, UFR des Sciences Pharmaceutiques, Laboratoire de Toxicologie, 146, rue Léo-Saignat, 33076 Bordeaux CEDEX

${ }^{\mathrm{h}}$ Université Paris 8, Département de géographie, 2, rue de la Liberté, 93526 Saint Denis cedex \& UMR Espace 6012, 98 bd Edouard Herriot, 06204, Nice, cedex 3, France

${ }^{\mathrm{i}}$ Institut Polytechnique LaSalle Beauvais, département STAI, rue P. Waguet BP 30313, 60026 Beauvais cedex, France

${ }^{j}$ INRA, Unité de Pathologie Végétale UR407, F-84140 Montfavet, France

*Corresponding author. Tel.: +33156295208.

E-mail address: sylvie.zini@afsset.fr

Correspondence address to which the proofs should be sent: Sylvie ZINI, Agence Française de Sécurité Sanitaire de l'Environnement et du Travail, 253, avenue du Général Leclerc, 94701 Maisons-Alfort, France 
Science of the Total Environment 408 (2010) 1659-1666

\begin{abstract}
For around two decades, artificial snow has been used by numerous winter sports resorts to ensure good snow cover at low altitude areas or more generally, to lengthen the skiing season. Biological additives derived from certain bacteria are regularly used to make artificial snow. However, the use of these additives has raised doubts concerning the potential impact on human health and the environment. In this context, the French health authorities have requested the French Agency for Environmental and Occupational Health Safety (Afsset) to assess the health risks resulting from the use of such additives. The health risk assessment was based on a review of the scientific literature, supplemented by professional consultations and expertise. Biological or chemical hazards from additives derived from the ice nucleation active bacterium Pseudomonas syringae were characterised. Potential health hazards to humans were considered in terms of infectious, toxic and allergenic capacities with respect to human populations liable to be exposed and the means of possible exposure. Taking into account these data, a qualitative risk assessment was carried out, according to four exposure scenarios, involving the different populations exposed, and the conditions and routes of exposure. It was concluded that certain health risks can exist for specific categories of professional workers (mainly snowmakers during additive mixing and dilution tank cleaning steps, with risks estimated to be negligible to low if workers comply with safety precautions). $P$. syringae does not present any pathogenic capacity to humans and that the level of its endotoxins found in artificial snow do not represent a danger beyond that of exposure to P. syringae endotoxins naturally present in snow. However, the risk of possible allergy in some particularly sensitive individuals cannot be excluded. Another important conclusion of this study concerns use of poor microbiological water quality to make artificial snow.
\end{abstract}

Keywords: Health risks, Pseudomonas syringae, Snowmaking, Water quality 


\section{Introduction}

An effect of the global warming is the the irregularity of the natural snow cover, in areas below an altitude of $2000 \mathrm{~m}$, like in the Alps, where a rise in winter night-time temperatures is coupled with a decrease in precipitation (OCDE, 2007). In this context, winter sports resorts are using more and more artificial snow to ensure a constant snow cover on their slopes (Vanham et al., 2009). In the past 20 years, a technological advance in the manufacture of artificial snow is the use of biological additives derived from a specific bacterium, an ice nucleation active strains of Pseudomonas syringae (here referred to as ice nucleation active Pseudomonas syringae strain, INAPSS), which has the capacity to optimise the freezing of water (Arny et al., 1976;Maki et al., 1974). Artificial snow production based on the use of such biological additives is now practiced worldwide and environmental concerns related to its use have been discussed for more than two decades (Goodnow et al., 1990a;Goodnow et al., 1990b). Used in France since 1992, INAPSS derived products have been suspended from 2005, at the request of the French National Ski Lift Union, following doubts concerning its potential impact on human health and the environment. In this context, both the French Ministries for Health and for Ecology have requested Afsset to assess the health risks linked to the use of INAPSS derived products to make artificial snow. Impacts on ecosystems have been the subject of a lot of publications : Rixen et al. (2003) have reviewed the impacts of artificial snow on soils and vegetation and have related the impacts on vegetation development (mitigation of soil frost, delay of the vegetation development, fertilising effect). In particular, in one of their recent papers, these authors have emphasized on the impact of ammonium nitrate, often used in snow additives, and its contribution to a growth of biomass and plant cover but to a decrease of species richness (Rixen et al., 2008). This paper focuses on the impacts of snow additive use on potential health hazards on humans, and more particularly on the use of Pseudomonas syringae as a nucleating agent used in snow additives.

The present paper is a condensed version of the conclusions and related recommendations for safe use of INAPPS derived products, which have been extensively detailed in a published report to French authorities (AFSSET, 2008).

\section{Methods}

The study was conducted based on a scientific review of the literature, supplemented by consultations and questionnaires designed to collect information. An exhaustive bibliographic review including articles, scientific reports, activity reports, and industrial technical data was considered. Two questionnaires were sent out to 23 French ski resorts that had used INAPSS derived products before the 2005 suspension by ski resort professionals. One questionnaire was designed to ascertain the ski resort personnel liable to come into contact with artificial snow. The second questionnaire concerned methods of production of artificial snow. The response rate for the questionnaires was 50\% and the data collected was judged to be significant and analysable.

In order to obtain information on the experiences of a number of private and public stakeholders in the field, the following organisations were consulted: Johnson Controls Neige, French National Ski Lift Union, French National Association of Ski Slope Managers and Winter Sport Resort Safety, French Group for the Study of Organisms 
Disseminated in the Environment. Also invited to contribute were: the French National Association of Artificial Snow Producers; the French Ski Federation; the French National Association of Mountain Resort Mayors; the International Commission for the Protection of the Alps; the Mountain Riders Association; Environment Canada; the Animal and Plant Health Inspection Service, the Biotechnology regulatory service and Plant Protection Service of the US Department of Agriculture, the US Environment Protection Agency, the Toxic substance control act service; the National Institute for Occupational Safety and Health, the Centre of Disease Control, the Office of Scientific and Technical Information, Consumer Product Safety Commission and Occupational Safety and Health Administration, USA.

The qualitative risk assessment method used was the method described by Zepeda Sein (Zepeda Sein, 1997) and adapted by Dufour \& Pouillot, (Dufour and Pouillot, 2002). In this method, the qualitative risk assessment entails combining the emission probability with the exposure probability. Estimations of the occurrence probability of "emission" and "exposure" events were performed separately, resulting in evaluation of the level of probability, by using the following qualifiers:

- nil: occurrence of the event is impossible;

- negligible: occurrence of the event would only be possible under exceptional circumstances;

- low: occurrence of the event is low, but possible under certain circumstances;

- $\quad$ moderate: the occurrence of the event is clearly possible;

- high: occurrence of the event is high.

The combination of the two probabilities leads to a lower probability than that of each of the initial probabilities, according to the following model:

- $\quad$ two probabilities with the same qualifier lead to the next qualifier down (low $\mathrm{x}$ low = negligible);

- $\quad$ two neighbouring probabilities lead to the next range down of the lowest probability (low x moderate $=$ negligible to low $)$;

- $\quad$ two non-neighbouring probabilities (but not opposing) lead to the lowest probability (low x high $=$ low);

two opposing probabilities lead to the next range up of the lowest probability (negligible $\mathrm{x}$ high $=$ negligible to low).

\section{Results}

\subsection{Principles for artificial snow production}


The principle of production of artificial snow is based on compressed air being projected through a calibrated orifice, sending small drops of water into ambient air at a negative temperature, in order to trigger the formation of snow crystals. The sudden expansion leads to sharp cooling around the nucleation site and induces immediate crystallisation of the water droplets, thereby forming nucleation cores. These cores in turn seed the atomised water flow and thereby trigger crystallisation of the droplets. The process can be split into 6 successive and/or concomitant stages: atomisation (spraying of fine water droplets into ambient air); nucleation (ice microcrystal formation called cores or nuclei to seed the sprayed air flow); seeding (meeting of atomised air flow with nucleation flow); dispersion (water is dispersed in ambient air by expansion of compressed air, or pressurised water expansion, or the air flow of a fan, or by a combination of all of these techniques); evaporation (water present at the edge of the droplet evaporates in contact with ambient air, enabling it to freeze) and convection (heat exchange between air and water, this step is important to maintain the water droplet in its crystallised solid state).

Nucleation and seeding are the two principal steps to obtain snow crystals. The performance of a snow production installation is dependent on climatic conditions. Parameters to be taken into account for artificial snow production include water and air temperatures, air humidity and water quality. In order to guarantee optimum snow production, water temperature must be close to $0^{\circ} \mathrm{C}$ and the air must be relatively cold and dry.

There are two conventional snow guns: the mono-fluid or "low pressure system" and the bi-fluid or "high-pressure system". In addition to snow guns, various other pieces of equipment are required:

- a water pumping station: a lake, reservoir, river or any other water source, such as marshland or drinking water system. Chemical and microbiological water quality can be variable from one source to another.

- a water storage basin, its volume ranging from a few thousand litres to a few tens of thousands of litres;

- a production building, containing pumps, control and regulating equipment, dilution system for the additive product and injection into the pipe network;

- pipes to transport pressurised air and water (10 to 80 bars for water), with a diameter of 15 to $20 \mathrm{~cm}$, being far wider at the pumping end, and generally buried at a depth of between 1.2 and $1.5 \mathrm{~m}$. They are made of ductile cast iron, steel or high-density polyethylene. At the end of the winter, the water supply is simply cut off and pipes are not cleaned. Maintenance operations are carried out in summer.

\subsection{The additives used for artificial snow production}

The additives used for artificial snow production act by triggering or optimising nucleation. Minerals (calcium, magnesium ions, kaolinite, etc.) naturally present in water form natural nucleation cores, essential for snow production, and seeding of water with mineral salts is sometimes performed when the water has a low mineral content (Hu and 
Michaelides, 2007). Nucleation cores can also be obtained using biological sources, such as $P$. syringae. This bacterium was demonstrated to be able to optimise freezing of water, by the synthesis of a specific protein which facilitates nucleation, leading to the formation of ice crystals at a temperature of $-2^{\circ} \mathrm{C}$ (Arny et al., 1976;Maki et al., 1974). To date, INAPSS derived products are the most widely used in the world to optimise the production of artificial snow.

$P$. syringae is a member of the phytopathogenic group of fluorescent bacteria belonging to the group of non-photosynthetic eubacteria. This Gram-negative bacillus is strictly aerobic, oxidase positive, mobile and produces endotoxins. Numerous strains have been described, but not all of which demonstrate the same ice-inducing capacity. Strain $31 a$ (ATCC 53543) has a strong ice-inducing capacity and is generally used for the production of artificial snow. $P$. syringae is a ubiquist, epiphytic bacterium, naturally present in the environment and generally lives in association with plants (Constantinidou et al., 1990;Lindemann et al., 1982). It is a psychrotrophic bacterium, having an optimum growth temperature of 25 to $28^{\circ} \mathrm{C}$. It can be found in concentrations of up to $10^{14}$ cells per hectare of agricultural land (Hirano and Upper, 1986). In water, the bacterium is naturally present at a concentration of 100 to 1,000 bacteria per litre and in snow, this concentration can naturally reach up to $10^{5}$ bacteria per litre (Morris et al., 2008). $P$. syringae produces phytotoxins or exotoxins (coronatine, tagetitoxin, phaseolotoxin and persicomycin) with plant tissues as the only target (Bender et al., 1999). Other substances produced can be toxic for certain bacteria, yeasts or moulds, such as syringomycin, syringopeptin and lipopeptides (Fiore et al., 2008), some of which could be haemolytic in vitro (Bender et al., 1999).

The genomes of at least three $P$. syringae strains have now been sequenced and the gene encoding of the synthesis of the ice-producing protein has been cloned and named ina or ice (Joardar et al., 2005). The sequence encoding of this protein is highly conserved among the multiple strains of $P$. syringae in which it has been characterized.

Sprang and Lindow (Sprang and Lindow, 1981) first demonstrated that a protein, named the Ice Nucleating Protein (INP), was responsible for the ice-inducing activity. This protein is located in the external membrane of the bacterium, with monomers of about $150 \mathrm{KDa}$. One monomer is formed by a N-terminal domain (around 180 amino-acids), probably involved in the phenomenon of maturation of the nucleation site, a central repetitive region (around 1,000 amino-acids), which seems essential in the ice-producing activity, and a C-terminal domain (around 50 amino-acids) presumably involved in the aggregation of monomers (Green et al., 1988). Under specific environmental conditions, monomers bind together to form the "nucleation site". After synthesis, the INP protein undergoes post-translational modifications, such as glycosylations and the addition of phosphatidyl-inositol residues, to form a lipoglycoprotein (Govindarajan and Lindow, 1988a; Kozloff et al., 1983; Kozloff et al., 1991; Turner et al., 1991; Wolber et al., 1986). These authors demonstrated that sugars and phospholipids play a major role in the nucleation process, but the molecular mechanism leading to the formation of ice crystals has not been completely clarified. It has been suggested that protein monomers could form aggregates of variable size, stabilised by the membrane. The size of the nucleation core therefore increases as the nucleation temperature increases: Govindarajan and Lindow demonstrated that the nucleation core is formed from a single monomer for 
1 nucleation activity at $-12^{\circ} \mathrm{C}$, whereas it may have 53 monomers at a temperature of $-3^{\circ} \mathrm{C}$ 2 (Govindarajan and Lindow, 1988b).

3 To date, interactions between the bacterial membrane, proteins and the ice crystal, 4 leading to the formation of the nucleation core are not totally understood (Kajava and Lindow, 1993;Mizuno, 1989; Warren et al., 1986). Studies by Wolber et al. (Wolber et al., 1986) demonstrate that the ice-inducing activity of the protein fraction is close to $-10^{\circ} \mathrm{C}$, whereas that of the whole cell is only $-4^{\circ} \mathrm{C}$, suggesting that the integrity of the bacterium could be crucial. Additionally, the protein conformation must be such that it can form hydrogen bonds with the ice. Whatever the mechanism, integrity of the bacterial cell is essential in obtaining a marked ice-inducing capacity. At temperatures close to $0^{\circ} \mathrm{C}$, aggregation of several nucleation proteins is necessary to trigger crystallisation of water, in order to form a large complex, stabilised by the external membrane of the bacterium. The size of the aggregate depends on various parameters, i.e. culture medium, physicochemical conditions and bacterial storage conditions (Lindow, 1995; Ruggles et al., 1993).

\subsection{Chemical and microbiological composition of additives derived from $P$. syringae}

According to one manufacturer, the final INAPSS derived product is obtained by the culturing of $P$. syringae strain $31 a$ in a fermenter, which is then centrifuged, frozen, lyophilisated, packaged and sterilized. The chemical composition of commercial INAPSS derived products is confidential. However, Goodnow (Goodnow, 1999) performed analysis and found it to be composed predominantly of proteins (30 to 50\%), carbohydrates (15\%), nucleic acids (10 to $11 \%$ ), metals (5 to $9 \%$ ) with alkaline earth salts $(\mathrm{Ca}, \mathrm{Fe}, \mathrm{K}, \mathrm{Mg}, \mathrm{Na}$ and $\mathrm{P}$ ) and transition metals $(\mathrm{Zn}, \mathrm{Mn}, \mathrm{Cu}, \mathrm{Ni}$ ) and at lower concentrations, aluminium, chromium and cadmium. According to the manufacturer, tests of the ice-inducing capacity of the final product are made by the drop test method (Vali, 1971). The manufactuer has also indicated that tests are realized to assure that the product does not present any culturable $P$. syringae cells nor cells of human pathogens.

The number of $P$. syringae cells released into the environment was evaluated on the basis of the usage protocol recommended by manufacturers. The literature indicated that $1 \mathrm{~g}$ of INAPSS derived product contained approximately $10^{11}$ to $10^{12}$ inactivated bacteria, each bacterium containing an average of 1 nucleation centre (Hendricks et al., 1992; Lawless R.J.J. and Laduca, 1992). By making the assumption that a 300 to 500-liter tank supplies a complete snowmaking installation for an operating period of 8 to 12 hours, (given the number of snow guns, flow rate and quantity of water used) and, as the manufacturer recommends the use of $300 \mathrm{~g}$ of product to treat $380 \mathrm{~m}^{3}$ of water sprayed by the snow guns, we evaluated that the product concentration inside the dilution tank was between 3 and $12 \mathrm{gl}^{-1}$, and the concentration in the snow guns after injection into pipes was $0.8 \mathrm{gm}^{-3}$, i.e. $0.8 \mathrm{mgl}^{-1}$, which could correspond to $8 \times 10^{10}$ to $8 \times 10^{11} \mathrm{P}$. syringae cells.m- ${ }^{3}$ of sprayed water. According to Morris et al. (Morris et al., 2008), this quantity of cells is higher by $10^{5}$ to $10^{6}$ times than the number of $P$. syringae cells naturally present in mountain waters.

44 
Science of the Total Environment 408 (2010) 1659-1666

\subsection{Identification and characterisation of possible dangers related to the INAPSS product}

Three main hazards to human health were considered, according to the INAPSS product composition. Those that were linked to $P$. syringae cells were: infection, toxicity and allergy. In addition, the danger linked to the capacity of a biological product to promote the development of microorganisms in water was considered.

\subsubsection{Alleged infectious capacity of $P$. syringae}

An exhaustive literature search relating to infections caused by $P$. syringae did not reveal any pathogenic capacity in humans. Two strains of $P$. syringae (ESC-10 and ESC-11) are used in plant protection products and were approved by the US Environmental Protection Agency (EPA), which concluded that there is no risk related to its normal use. These products have been used for more than 10 years in the biological control of postharvesting blight in various fruits, some of which are intended to be eaten raw. Moreover, the bacteria cannot survive at temperatures of above $32^{\circ} \mathrm{C}$, and cannot therefore multiply in humans or birds, which have a higher body temperature. Considering this data, the authors conclude that the infectious capacity of INAPSS derived products in humans is non-existent.

\subsubsection{Dangers relating to endotoxins}

As for any Gram-negative bacteria, the external membrane of $P$. syringae contains lipopolysaccharides, of which the lipid-A part corresponds to the endotoxin. Endotoxins are known to trigger inflammatory and haemodynamic responses following contact with mucous membranes and skin; these responses involve non-specific or natural immunity and are responsible for asthma and pulmonary and respiratory dysfunctions.

A data sheet for INAPSS derived products packaged in bags reports the presence of endotoxins, with the warning that inhalation of dust can cause a cough and irritation of the upper airways. However, the endotoxin concentration is below those known to induce a pathogenic effect in humans, according to the US Food and Drug Administration.

The toxicity studies conducted on rodents by the US Food and Drug Research Laboratories did not reveal any significant hypersensitisation, contact sensitisation or signs of irritation or erythema (FDRL, 1985a;FDRL, 1985b;FDRL, 1985c;FDRL, 1985d;FDRL, 1987a;FDRL, 1987b;FDRL, 1987c). The inflammatory reaction in the eye of rats after injection (FDRL, 1985d), and in the respiratory tract of rabbits following aerosol inhalation (FDRL, 1985b), was explained by the FDRL as an experimental artefact and not as a result of the product (FDRL, 1987c).

Acute toxicity studies on rats demonstrated a statistically significant increase in lung weight and hypertrophy of the tracheobronchial lymph nodes, but with no signs of infection. It was concluded as being a simple irritation reaction (Goodnow et al., 1990b; Goodnow, 1989). However, it was demonstrated that high levels of endotoxins are present in all phases of production of artificial snow, especially in the mixing phase and in the plume of the snow guns (Kulman, 1993a). However, with LPS being inherent in any Gram-negative bacteria, the endotoxins identified at the exit of the snow guns can be produced by any Gram-negative bacteria present in the water used for artificial snowmaking. 
1 Considering that humans in their normal environment are regularly exposed to $P$. syringae bacteria, and therefore to the endotoxins that it produces, it was concluded that 3 INAPSS derived products did not present any additional danger to that of natural 4 exposure.

5

\subsubsection{Dangers of allergies}

$P$. syringae contains antigenic structures which could stimulate specific immune responses if they come into contact with mucous membranes (respiratory, ocular and gastrointestinal), skin or even systemic contact (wounds). Thus, the presence of secretory antibodies has been reported in humans, (Rylander et al., 1982) and the immunogenicity of $P$. syringae was established (Ovod et al., 1996; Shimazu et al., 2003). However, no precise data is available concerning the specific immune responses following experimental exposure to $P$. syringae antigens, as well as cellular and molecular responses. No scientific reference is available relating to other types of hypersensitivity or auto-immune diseases.

Given the small number of studies available, it was not possible to determine which are actually related to hypersensitivity conditions concerning reactions to $P$. syringae in humans or animals. Additional studies are clearly preferable. The other ingredients of INAPSS products were not considered, since they were judged to be non-antigenic.

\subsubsection{Dangers relating to the development of other microorganisms}

Water used to prepare and produce artificial snow comes from the natural environment and can potentially contain pathogenic microorganisms. As a source of nutrients, INAPSS derived products can facilitate the development of microorganisms naturally present in water (CEMAGREF, 2003;Kulman, 1993). Inside the dilution tank, the concentration of INAPSS derived products is in the range of 3 to $12 \mathrm{gl}^{-1}$. Given the composition of the product (see above), a concentration of $12 \mathrm{gl}^{-1}$ corresponds to approximately $6 \mathrm{gl}^{-1}$ of proteins and $3 \mathrm{gl}^{-1}$ of carbohydrates. These concentrations can be compared with those of a standard bacterial culture medium (i.e. for Escherichia coli), which contains approximately $9.8 \mathrm{gl}^{-1}$ of proteins (or amino acids) and $0.86 \mathrm{gl}^{-1}$ of carbohydrates. It was concluded that the amounts of nutrients supplied by artificial snow manufactured products were sufficient to induce microbial development. Thus, Kulman (Kulman, 1993) reported the presence of approximately $10^{5} \mathrm{CFU} / \mathrm{ml}$ of Gram-negative microorganisms in the mixing tank and $10^{3}$ to $10^{4} \mathrm{CFU} / \mathrm{ml}$ in the snow and concluded that INAPSS derived products may encourage the development of microorganisms contained in the dilution water inside the tank. Microorganisms can also develop biofilms inside the snowmaking pipes. This data suggests that the amounts of nutrients supplied are sufficient to trigger the development of microorganisms in the tank.

\subsection{Identification of exposed populations, scenarios and routes of exposure}

The data presented below were obtained from responses to two questionnaires sent out to 23 French ski resorts. From these results, it was concluded that INAPSS derived products were not used systematically and constantly during the artificial snow production period, but generally, both before the resort was opened to the public and at the start of the season, in order to ensure a stable cover to receive the first natural snow fall, and during the season to compensate for a lack of snow and to extend the opening season. Between 
1992 and 2005, the mean duration for the use of INAPSS derived products ranged from a few days to more than 50 days per season. Snow guns may be triggered both at night and during the day when the slopes were open to the public. In rare cases, a few resorts stated that they only used snow guns at night or that they closed the slopes during the use of snow guns. INAPSS products were often in use on the most-used areas (lower slopes in the resort, slope intersections) and for beginners' slopes requiring easier skiing conditions. The exposure to INAPSS derived products concerned all users of the ski slopes (adults and children) and all of the staff responsible for slope management: snowmakers (production of artificial snow), snow grooming machine drivers (maintenance), slope managers and rescue workers (slope safety), instructors and ski lift operators.

From these observations, four main exposure scenarios have been identified, taking into account the people concerned and the routes of exposure (Table I): 1) during the preparation of the mixture in the tank; 2) during the cleaning of the mixing equipment; 3 ) from exposure to the artificial snow plume; 4) from exposure to artificial snow on the ground.

For these 4 scenarios, different routes of exposure were identified:

inhalation of powder from the raw product: during the preparation of the mixture in the tank; preparation of the mixture in the tank, from the artificial snow plume;

- $\quad$ contact with skin or mucous membranes (hands, face, mouth, eyes): during the preparation of the mixture in the tank; during the cleaning of the mixing equipment, during contact with the artificial snow plume, during contact with artificial snow on the ground;

- $\quad$ ingestion of the product or ingestion of snow: during the preparation of the mixture in the tank; during the cleaning of the mixing equipment, during contact with the artificial snow plume, during contact with artificial snow on the ground.

\subsection{Health risk assessment}

No quantitative data concerning the type of person exposed and the dose-effect relationships of exposure to INAPSS derived products in humans was available. Consequently, the health risk related to exposure for the above-mentioned types of people can only be assessed qualitatively. The qualitative risk assessment method used was the method described by Zepeda Sein (Zepeda Sein, 1997) and adapted by Dufour \& Pouillot, (Dufour and Pouillot, 2002). However, this method has some limitations, such as insufficient basic data concerning exposure and the subjective nature of assessment of the different probabilities adopted.

The "probability of emission" refers to the existence or emission of a hazard, in the present case corresponding to the presence of the INAPSS products, in the immediate environment of the person. The "probability of exposure" refers to the conditions and occurrence of human exposure, in the immediate environment. The qualitative risk assessment was implemented successively for the 4 main exposure scenarios detailed

46 above. Results concerning the health risk assessment are summarised in Table II. 


\subsubsection{Risk assessment during mixture preparation in the tank}

The only professional category liable to be exposed to the raw product is the snowmakers. These professionals noticed that, although the tank opening was designed to limit contact with the product (about $20 \mathrm{~cm}$ diameter), some powder can be released upon opening the bag and when pouring its contents into the tank. Thus, preparation is considered as a possible stage of contact with the raw product. The routes of exposure identified with the above-mentioned scenario were inhalation and contact with the skin and mucous membranes (hands, face, mouth, eyes).

With respect to exposure to the raw product during preparation, and when the manufacturer's recommended protocols are respected (wearing Personal Protective Equipment, PPE), it was considered that the probability of emission was "moderate", and the probability of exposure was "low". The estimated risk is therefore negligible to low. However, in practice, snowmakers are not always compliant with the safety precautions recommended by the manufacturer. In this case, it was considered that the probability of emission was "moderate" and the probability of exposure was "high". The estimated risk under these special circumstances is low to moderate. Concerning exposure to the diluted product in the tank, it can be considered that the probability of emission was "moderate" and the probability of exposure was "negligible". The estimated risk is therefore "negligible". In practice, the precautions (wearing PPE) and the usage protocols specified by the manufacturer are not always respected. In this case, the authors consider the probability of emission to be "moderate" and the probability of exposure to be "low". The estimated risk is therefore negligible to low.

\subsubsection{Risk assessment during cleaning of the mixing equipment}

After the use of the mixture, the empty tank is rinsed and cleaned. The snowmaker is the only professional category liable to be exposed to left-over product during this dilution tank cleaning stage. Mixture residues may adhere to the inside walls of the tank and are liable to be splashed during cleaning. The tank opening has been designed to limit splashing and the manufacturer's protocol specifies that gloves and protective goggles must be worn. However, without personal protective equipment, contact with the diluted product is possible, mainly from the filling of the tank with the water jet and the use of the brush. In such cases, the route of exposure identified was through contact with the skin and mucous membranes (hands, face, mouth and eyes).

With respect to equipment cleaning by the snowmaker and when the manufacturer's recommendations and protocol were complied with, it was considered that the emission probability was "low" and the exposure probability was "low". The estimated risk was therefore negligible. In practice, precautions are not always respected. In this case, it was considered that the probability of emission was "low" and the probability of exposure was "moderate". The estimated risk in these special circumstances was therefore negligible to low.

\subsubsection{Risk assessment for exposure from the snow plume}

The persons liable to be exposed to the snow gun plumes are both skiers and professionals working with them. The risk assessment took into account the quantity of $P$.

46 syringae cells emitted into the environment through the use of INAPSS derived products, 
i.e. $10^{5}$ to $10^{6}$ times higher than the quantity naturally present in mountain water. Exposure routes are inhalation of aerosols and contact with uncovered parts of the body, mainly the face. It was considered that skiwear, gloves and goggles are likely to limit the contact with the skin and mucous membranes.

This analysis took into account all categories of skiers, since snow guns are positioned on the large majority of slopes. Directly of concern were ski schools for young children, because these are generally located in the lower and frequently used parts of resorts. In view of the dilution of INAPSS derived products by the snow, the occurrence and the duration of potential contact, it was considered that the probability of emission was "negligible" and the probability of exposure was "low" for adult or child skiers. The estimated risk for adult or child skiers was therefore nil to negligible.

Among the professional categories, three different cases were considered:

- $\quad$ snowmakers who are liable to work regularly with operating snow guns; therefore representing the most exposed professional category; - $\quad$ slope managers, slope safety officers, ski instructors and rescue workers: their conditions of exposure are identical to those of skiers, but they are continuously exposed throughout the season;

- professionals responsible for snow grooming and handling: they are protected by the cab of the grooming machine and they usually operate once the snow guns have stopped. It was concluded that these professionals are not exposed to the snow gun plumes. Also, ski lift operators are not affected, since the plumes are not directed towards ski lifts.

Considering the emission parameter, it was considered that the probability was "negligible" in light of the dilution of the product.

In light of these exposure conditions, it was considered that the probability of exposure to snow plumes was "moderate" to "high" for snowmakers; "low" for slope managers, slope safety officers, ski instructors and rescue workers; "negligible" for snow grooming professionals and those in charge of ski lifts.

Consequently, the estimated risks were "negligible" to "negligible to low" for snowmakers; "nil to negligible" for slope managers, slope safety officers, ski instructors and rescue workers; "nil" for snow grooming machine drivers and ski lift operators.

\subsubsection{Risk assessment for the exposure to artificial snow on the ground}

As artificial snow is spread over the slope and mixed with natural snow, the concentration of INAPSS derived products in the snow is therefore further diluted. All slope users and skiing professionals are liable to be exposed to this snow, according to the same conditions and routes of exposure. The main route of exposure is contact with the skin and mucous membranes, but ingestion is possible, especially for children. In view of the additional dilution rate of the product, the emission probability was considered to be "negligible".

It was considered that the probability of exposure to snow on the ground was "negligible" for adult skiers and professionals and "moderate" for children. Consequently, the estimated risks were "nil" for adult skiers and professionals and "negligible" for children. 


\subsubsection{The importance of water quality for the production of artificial snow}

Two studies, conducted in a French ski resort, highlighted the presence of microorganisms in the water used for the production of artificial snow:

- $\quad$ a series of analyses performed in 2003 at a French ski resort on the water used in the snowmaking equipment using INAPSS derived products indicated the presence of faecal coliforms, including Escherichia coli and enterococci in the water of the supply stream, and enterobacteria, streptococci, staphylococci and enterococci inside the mixing tank (CEMAGREF, 2003). The total coliform and E. coli concentrations measured were twice as high in the tank. This increase was attributed to probable bacterial proliferation induced by the addition of INAPSS derived products, and by storage of the mixture in the tank for more than 24 hours. It should also be noted that no $P$. syringae colonies were detected (either in the water sampled or in the mixing tanks).

- $\quad$ a second study performed by the Haute-Savoie County-level Department of Health and Social Affairs (DDASS) in 2006 and 2007 highlighted the presence of group-2 norovirus, total coliforms, Escherichia coli, enterococci and anaerobic bacterial spores in the water of a storm-water tank (reservoir used for the production of artificial snow) at a ski resort not using INAPSS derived products.

A hypothesis was also put forward that biofilms could develop inside pipes of the artificial snowmaking system. Biofilm development seems to be negligible during operation, given the pressure and the low water temperature in winter. It also seems negligible in summer, due to the disconnection of the water supply from the equipment. In contrast, biofilm development could be possible if emptying were incomplete, in the presence of siphons or ox-bows, for example.

In conclusion, considering the survival of the microorganism at low temperatures (Gawande and Griffiths, 2005;Rogers et al., 2004;Smith and Schaffner, 2004), the exposure of skiers and professionals to microorganisms from artificial snow made with water of poor microbiological quality was considered plausible.

\subsubsection{Contamination of drinking water catchments}

The hypothesis according to which melting artificial snow containing pathogenic microorganisms may contaminate a drinking water catchment was also considered. According to the information provided by the Massif Alpin DDASS, numerous catchments for drinking water supply are located in ski areas equipped with artificial snowmaking systems, or even immediately adjacent to the ski slopes concerned. Mountainous limestone areas (Pyrenees, Jura, Vercors, Southern Alps), known as "karstic" areas, are particularly affected by this type of situation, since the infiltrating water can reach deep aquifers and be found at water outlets within a few hours. These flow speeds (up to a few hundred metres per hour) and the frequent absence of surface soil do not allow filtration of the water. During snow melting periods, the soil, when it exists, is saturated with water, and the hypothesis of contamination of an aquifer or catchment by water from artificial snow containing potentially pathogenic microorganisms is possible. It was considered that exposure of people to microorganisms produced by the melting of artificial snow of poor microbiological quality via the mains water system was an acceptable hypothesis in certain unfavourable conditions. 


\section{Discussion}

Most additive products presented by manufacturers as aiding the production of artificial snow are derived from a lyophilized biological preparation containing the inactivated bacterium $P$. syringae. This application exploits the ice-nucleating capabilities of the bacterium, promoted by an outer membrane-associated protein, INP. The present study shows that the chemical composition of manufactured INAPSS derived products does not indicate the presence of any chemical substances toxic to humans at the concentrations used. On a microbiological level, INAPSS derived products are only composed of inactivated strain 31a of $P$. syringae, an epiphytic bacterium, naturally present in the environment.

The health hazards for humans of INAPSS derived products were studied on the basis of an assumption of infectious, toxicity and allergenic capacity. The scientific literature does not report any infectious capacity of $P$. syringae for humans. Also, it was considered that $P$. syringae and consequently, INAPSS derived products, do not present any pathogenic capacity for humans. While data supplied by manufacturers and identified studies were deemed to be insufficient to conclude that there is any health hazard linked to endotoxins, considering that in their normal environment humans are regularly exposed to $P$. syringae endotoxins and those from any other Gram-negative bacteria, it was concluded that INAPSS products do not represent an additional danger to that of natural exposure to $P$. syringae endotoxins. The scientific documentation relating to the human allergenic capacity of $P$. syringae was very limited and conclusions with respect to the potential allergenic effect of INAPSS derived products cannot be reached. Considering that humans are currently exposed in their normal environment to $P$. syringae, and that repeated contact with high doses of antigens causes tolerance rather than hypersensitivity, the danger linked to allergy to INAPSS related products was considered to be minimal. However, the risk of possible allergy in some particularly sensitive individuals cannot be excluded.

During the mixing and cleaning phases of INAPSS derived product preparation, snowmakers are the only category of people potentially exposed to the product. The risk was estimated to be negligible to low if workers comply with safety precautions recommended, but it was estimated higher if snowmakers operated without PPE. Thus for snowmakers, the systematic wearing of PPE during the preparation phase was recommended. It was also considered that the use of a respiratory protection would be necessary, whereas this was not recommended by the manufacturer. Moreover, it is advised to avoid procedures that are different from the manufacturer's protocol, such as pre-mixing the product in a bucket of water. Concerning exposure to artificial snow from the plume of snow guns, the estimated risk was found negligible to low for snowmakers and nil to negligible for skiers (adults and children), slope managers, slope safety officers, instructors and rescue workers and nil for snow grooming machine drivers and ski lift operators. Concerning exposure to artificial snow on the ground, the estimated risk was nil to negligible for all the people concerned.

The artificial snowmaking process generally uses natural water of variable quality, that includes microorganisms pathogenic to humans (staphylococci, viruses, etc.). It appeared that INAPSS derived products were a source of nutrients which can facilitate the development of such microorganisms. In addition, considering the susceptibility of 
aquifers and drinking water catchments in mountain areas to pollution, the thawing of artificial snow made from water of poor microbiological quality may have an impact on the sanitary quality of water intended for the production of water for human consumption. Without a specific regulation specifying the water quality to be used in snowmaking, we recommend the use of water of a quality that is fit for human consumption and advise keeping the mixture in the dilution tank for no more than 24 hours. Concerning the protection of drinking water catchments, it seems pertinent to take into account in the definition of protection perimeters by the French administration, the ski resort practices in terms of artificial snow production with the use of additives and/or water of poor chemical and/or microbiological quality.

\section{Conclusion}

In order to reduce the occurrence of dangers during the production of artificial snow, it was recommended, in view of the health risk assessment conclusions, to systematically wear protective equipment (goggles, gloves and mask) when preparing the snowmaking product solution, to use water with a good microbiological quality for the dilution of the product, and to store the mixture for no more than 24 hours. In addition, as part of a health monitoring approach, it would be pertinent to further consider the potential impacts linked to the use of additives other than INAPSS derived products, and in particular those used to maintain snow coverage, which could lead to impacts on the soil and the quality of water sources, through snow melt.

\section{Acknowledgments}

Our thanks go to Xavier Bruni, Valloire ski resort slope manager; Jacques Viallet, Head of the "artificial snow" team at the Valloire ski resort; André Grogniet, National Association of managers of ski slopes and winter sport resort safety; Gaston Plaisance, Les Ménuires ski resort slope manager; Jean Paul Hudry, Snowmaker, Les Ménuires,Saint Martin de Belleville ski resort; Serge Riveill, French National Ski Lift Union; Maxime Rougeaux, Johnson Controls Neige; Claude Alabouvette, French National Institute for Agricultural Research, Dijon.

\section{References}

AFSSET. Assessment of the health risks linked to the use of additive for the production of artificial snow. AFSSET Report 2008.

Arny DC, Lindow SE, Upper CD. Frost sensitivity of Zea mays increased by application of Pseudomonas syringae. Nature 1976; 262: 282-284.

Bender CL, arcon-Chaidez F, Gross DC. Pseudomonas syringae phytotoxins: mode of action, regulation, and biosynthesis by peptide and polyketide synthetases. Microbiol Mol Biol Rev 1999; 63: 266-292.

CEMAGREF. Neige de culture et Snomax: Quels impacts sur l'environnement ? CEMAGREF Report 2003. 
Science of the Total Environment 408 (2010) 1659-1666

Constantinidou HA, Hirano SS, Baker LS, Baker LS, Upper CD. Atmospheric dispersal of ice nucleation-active Bacteria : the role of rain. Phytopathology 1990; 80: 934-937.

Dufour B, Pouillot R. Approche qualitative du risque. Epidémiol et santé anim $2002 ; 35-43$.

FDRL. Acute inhalation toxicity study of Snomax in Sprague Dawley rats. Food and Drug Research Laboratories Inc Waverly NY Report 1985a.

FDRL. Acute oral toxicity study of P.syringae 31a in New Zealand White rabbits. Food and Drug Research Laboratories Inc Waverly NY Report 1985 b.

FDRL. Primary dermal irritation study of P.syringae 31a in New Zealand White Rabbits. Food and Drug Research Laboratories Inc Waverly NY Report 1985c.

FDRL. Primary eye irritation study of P.syringae 31a in New Zealand White rabbits. Food and Drug Research Laboratories Inc Waverly NY Report 1985d.

FDRL. Acute dermal toxicity study of Snomax (EPA TSCA) in albino guinea pigs. Food and Drug Research Laboratories Inc Waverly NY. 1-4-1987a. Ref Type: Report

FDRL. Acute inhalation toxicity study of Snomax (0.08\% solution) in Sprague Dawley rats. Food and Drug Research Laboratories Inc Waverly NY Report 1987b.

FDRL. Acute inhalation toxicity study of Snomax (particulates) in Sprague Dawley rats. Food and Drug Research Laboratories Inc Waverly NY Report 1987c.

Fiore A, Mannina L, Sobolev AP, Salzano AM, Scaloni A, Grgurina I, Fullone MR, Gallo M, Swasey C, Fogliano V, Takemoto JY. Bioactive lipopeptides of icenucleating snow bacterium Pseudomonas syringae strain 31R1. FEMS Microbiol Lett 2008; 286: 158-165.

Gawande PV, Griffiths MW. Growth history influences starvation-induced expression of uspA, grpE, and rpoS and subsequent cryotolerance in Escherichia coli O157:H7. J Food Prot 2005; 68: 1154-1158.

Goodnow, R. A. Microbiologic sheet for Snomax. Eastman Kodak Company. Intern Manufacturer Report 1999.

Goodnow RA, Harrison MD, Morris JD, Sweeting KB, Laduca RJ. Fate of Ice Nucleation-Active Pseudomonas syringae Strains in Alpine Soils and Waters and in Synthetic Snow Samples. Appl Environ Microbiol 1990a; 56: 2223-2227.

Goodnow RA, Katz G, Haines DC, Terrill JB. Subacute inhalation toxicity study of 
Goodnow, RA. Two-week inhalation toxicity study with Snomax in the rat. Eastman Kodak Company Intern Manufacturer Report 1989.

Govindarajan AG, Lindow SE. Phospholipid requirement for expression of ice nuclei in Pseudomonas syringae and in vitro. J Biol Chem 1988a; 263: 9333-9338.

Govindarajan AG, Lindow SE. Size of bacterial ice-nucleation sites measured in situ by radiation inactivation analysis. Proc Natl Acad Sci USA 1988b; 85: 13341338.

Green RL, Corotto LV, Warren GJ. Deletion mutagenesis of the ice nucleation gene from Pseudomonas syringae S203. Mol Gen Genet 1988; 215: 165-172.

Hendricks, D., Ward, P. J., and Orrego, S. A. Production of microorganisms having ice nucleation activity. [U.S. Patent 5,137,815] 1992.

Hirano SS, Upper CD. Temporal, spatial and genetic variability of leaf-associated bacterial populations. In: Fokkema NJ, Van Den Heuvel J, editors. Microbiology in phyllosphere. Cambridge University Press, London, 1986, pp. 235-251.

$\mathrm{Hu}$ XL, Michaelides A. Ice formation on kaolinite: Lattice match or amphoterism? Surface Science 2007; 601: 5378-5381.

Joardar V, Lindeberg M, Jackson RW, Selengut J, Dodson R, Brinkac LM, Daugherty SC, Deboy R, Durkin AS, Giglio MG, Madupu R, Nelson WC, Rosovitz MJ, Sullivan S, Crabtree J, Creasy T, Davidsen T, Haft DH, Zafar N, Zhou L, Halpin R, Holley T, Khouri H, Feldblyum T, White O, Fraser CM, Chatterjee AK, Cartinhour S, Schneider DJ, Mansfield J, Collmer A, Buell CR. Whole-genome sequence analysis of Pseudomonas syringae pv. phaseolicola 1448A reveals divergence among pathovars in genes involved in virulence and transposition. $\mathrm{J}$ Bacteriol 2005; 187: 6488-6498.

Kajava AV, Lindow SE. A model of the three-dimensional structure of ice nucleation proteins. J Mol Biol 1993; 232: 709-717.

Kozloff LM, Schofield MA, Lute M. Ice nucleating activity of Pseudomonas syringae and Erwinia herbicola. J Bacteriol 1983; 153: 222-231.

Kozloff LM, Turner MA, Arellano F, Lute M. Phosphatidylinositol, a phospholipid of ice-nucleating bacteria. J Bacteriol 1991; 173: 2053-2060.

Kulman, G. Health Hazard Evaluation Report No. 89-348-228 SNOMAX. National Institute for Occupational Safety and Health 1993.

Lawless R.J.J. and Laduca, R. J. Fermentation of microrganisms having ice nucleation activity using a temperature change. [US Patent 5,153,134]. 1-1-1992. Ref Type: Patent 
Lindemann J, Constantinidou HA, Barchet WR, Upper CD. Plants as Sources of Airborne Bacteria, Including Ice Nucleation-Active Bacteria. Appl Environ Microbiol 1982; 44: 1059-1063.

Lindow SE. Membrane fluidity as a factor in production and stability of bacterial ice nuclei active at high subfreezing temperatures. Cryobiology 1995; 32: 247-258.

Maki LR, Galyan EL, Chang-Chien MM, Caldwell DR. Ice nucleation induced by pseudomonas syringae. Appl Microbiol 1974; 28: 456-459.

Mizuno H. Prediction of the conformation of ice-nucleation protein by conformational energy calculation. Proteins 1989; 5: 47-65.

Morris CE, Sands DC, Vinatzer BA, Glaux C, Guilbaud C, Buffiere A, Yan S, Dominguez $\mathrm{H}$, Thompson BM. The life history of the plant pathogen Pseudomonas syringae is linked to the water cycle. ISME J 2008; 2: 321-334.

OCDE. Climate change in the european Alps: adapting winter tourism and natural hazards management. Shardul Agrawala Report 2007.

Ovod V, Rudolph K, Knirel Y, Krohn K. Immunochemical characterization of O polysaccharides composing the alpha-D-rhamnose backbone of lipopolysaccharide of Pseudomonas syringae and classification of bacteria into serogroups $\mathrm{O} 1$ and $\mathrm{O} 2$ with monoclonal antibodies. J Bacteriol 1996; 178: 6459-6465.

Rixen C., Stoeckli V., Ammann W. Does articificial snow production affect soil and vegetation of ski pistes : a review. Perspectives in Plant Ecology, Evolution and Systematics 2003; 5: 219-23.

Rixen C., Huovinen C., Huovinen K., Stöckli V., Schmid B. A plant diversity $\times$ water chemistry experiment in subalpine grassland, Perspectives in Plant Ecology, Evolution and Systematics 2008; 10: 51-61. survival in ice. Med Hypotheses 2004; 63: 773-777.

Ruggles JA, Nemecek-Marshall M, Fall R. Kinetics of appearance and disappearance of classes of bacterial ice nuclei support an aggregation model for ice nucleus assembly. J Bacteriol 1993; 175: 7216-7221.

Rylander R, Wold A, Haglind P. Nasal antibodies against gram-negative bacteria in cotton-mill workers. Int Arch Allergy Appl Immunol 1982; 69: 330-334.

Shimazu M, Nguyen A, Mulchandani A, Chen W. Cell surface display of organophosphorus hydrolase in Pseudomonas putida using an ice-nucleation protein anchor. Biotechnol Prog 2003; 19: 1612-1614. 
1 Smith S, Schaffner DW. Evaluation of a Clostridium perfringens predictive model, developed under isothermal conditions in broth, to predict growth in ground beef during cooling. Appl Environ Microbiol 2004; 70: 2728-2733.

Sprang ML, Lindow SE. Subcellular localization and partial characterization of ice nucleating activity in Pseudomonas syringae and Erwinia herbicola. Phytopathology $1981 ; 256$.

Turner MA, Arellano F, Kozloff LM. Components of ice nucleation structures of bacteria. J Bacteriol 1991; 173: 6515-6527.

9 Vali G. Quantitative Evaluation of Experimental Results an the Heterogeneous Freezing Nucleation of Supercooled Liquids. J Atmos Sci 1971; 28: 402-409.

Vanham D, Fleischhacker E, Rauch W. Impact of snowmaking on alpine water resources management under present and climate change conditions. Water Sci Technol 2009; 59: 1793-1801.

14 Warren G, Corotto L, Wolber P. Conserved repeats in diverged ice nucleation structural genes from two species of Pseudomonas. Nucleic Acids Res 1986; 14: 8047-8060.

Wolber PK, Deininger CA, Southworth MW, Vandekerckhove J, van MM, Warren GJ. Identification and purification of a bacterial ice-nucleation protein. Proc Natl Acad Sci USA 1986; 83: 7256-7260.

Zepeda Sein, C. Méthodes d'évaluation des risques zoosanitaires lors des échanges internationaux. Séminaire sur la sécurité zoosanitaire des échanges dans les Caraïbes. 